\title{
Antioxidant and antihypertensive activity of bovine whey protein concentrate enzymatic hydrolysates
}

\author{
Hidrolizados enzimáticos con actividad antioxidante y antihipertensiva obtenidos del concentrado \\ proteico del suero lácteo bovino
}

\author{
Xochitl Tovar-Jiménez ${ }^{1 *}$, Alejandro Téllez-Jurado', Carlos Alberto Gómez-Aldapa², Yuridia Mercado-Flores ${ }^{1}$ y Ainhoa \\ Arana-Cuenca ${ }^{1}$ \\ Universidad Politécnica de Pachuca, Carr. Pachuca-Cd. Sahagún Km. 20, Ex-Hacienda de Santa Bárbara, C.P. 43830 Zempoala \\ Hidalgo. México. \\ 2 Área Académica de Química, Universidad Autónoma del Estado de Hidalgo, Carr. Pachuca - Tulancingo Km. 4.5, Mineral de \\ la Reforma. Hidalgo. C.P. 42184
}

\section{ABSTRACT}

Whey is a polluting by-product of cheese processing. However, it has valuable nutritional properties that can be exploited for diverse applications. Research has shown how whey proteins enzymatic hydrolysis releases bioactive peptides. In the present study, the whey protein concentrate (WCP) hydrolysis was performed using purified Sporisorium reilianum aspartyl protease (Eap1), with commercial enzymes chymotrypsin (C) and trypsin ( $\mathrm{T}$ ), as well as different enzymatic combinations in order to determine which enzyme or combination allowed for the release of peptides presenting the highest antioxidant and antihypertensive activity levels. Our results indicated that hydrolysis with Eap1 releases the best-performing peptides ( $1467.30 \mathrm{mM}$ AAEAA/100g WCP; $835.20 \mathrm{mM} \mathrm{FeSO}_{4} / 100 \mathrm{~g}$ WCP and $83.36 \%$ ACE inhibition) in comparison with individual enzymes (Q: $1164.60 \mathrm{mM}$ AAEAA/100g WCP; $305.35 \mathrm{mM} \mathrm{FeSO}_{4} / 100 \mathrm{~g} \mathrm{WCP} ; 92.35 \%$ ACE inhibition and T: $354.87 \mathrm{mM}$ AAEAA/100g WCP; $205.82 \mathrm{mM}$ $\mathrm{FeSO}_{4} / 100 \mathrm{~g} \mathrm{WCP} ; 83.8 \%$ ACE inhibition) and their combinations (Eap1-C: $1050.23 \mathrm{mM}$ AAEAA/100g WCP; $399.09 \mathrm{mM}$ $\mathrm{FeSO}_{4} / 100 \mathrm{~g}$ WCP; $85.58 \%$ ACE inhibition, Eap1-T: $882.5 \mathrm{mM}$ AAEAA/100g WCP; $220.63 \mathrm{mM} \mathrm{FeSO}_{4} / 100 \mathrm{~g} \mathrm{WCP} ; 85.40 \%$ ACE inhibition, C-T: $994.67 \mathrm{mM}$ AAEAA/100g WCP; $310.43 \mathrm{mM}$ $\mathrm{FeSO}_{4} / 100 \mathrm{~g} \mathrm{WCP} ; 61.27 \%$ ACE inhibition and C-Eap1-T: 93.23 mM AAEAA/100g WCP; 23.3 mM FeSO $/ 100 \mathrm{~g} \mathrm{WCP} ; 38.35 \%$ ACE inhibition).

Keywords: antioxidant peptides; antihypertensive peptides; protein concentrate from bovine whey; aspartyl protease of Sporisorium reilianum; commercial enzymes.

\section{RESUMEN}

El lactosuero es considerado un subproducto contaminante de la industria quesera, sin embargo, cuenta con importantes propiedades nutrimentales que pueden ser aprovechadas. Estudios indican que la hidrólisis enzimática de sus proteínas permite liberar péptidos bioactivos. En este estudio, se realizó la hidrólisis del concentrado proteico del lactosuero (WCP) por acción de la aspartil proteasa purificada de Sporisorium reilianum (Eap1), con las enzimas comerciales quimotripsina (C), tripsina $(\mathrm{T})$ y de su combinación enzimáti$\mathrm{ca}$, con la finalidad de determinar que enzima permite liberar péptidos con mejor actividad antioxidante y antihipertensiva. Los resultados indicaron que la Eap1 libera péptidos con mejor actividad (1467.30 mM AAEAA/100g WCP; $835.20 \mathrm{mM}$ $\mathrm{FeSO}_{4} / 100 \mathrm{~g} \mathrm{WCP} ; 83.36 \%$ inhibición ACE) en comparación con las enzimas individuales (Q: $1164.60 \mathrm{mM}$ AAEAA/100g WCP; 305.35 mM FeSO $/ 100 \mathrm{~g} \mathrm{WCP} ; 92.35 \%$ inhibición ACE у т: $354.87 \mathrm{mM}$ AAEAA/100g WCP; $205.82 \mathrm{mM} \mathrm{FeSO} / 100 \mathrm{~g}$ WCP; $83.8 \%$ inhibición ACE) y sus combinaciones (Eap1-C: $1050.23 \mathrm{mM}$ AAEAA/100g WCP; $399.09 \mathrm{mM} \mathrm{FeSO}_{4} / 100 \mathrm{~g} \mathrm{WCP}$; $85.58 \%$ inhibición ACE, Eap1-T: 882.5 mM AAEAA/100g WCP; $220.63 \mathrm{mM} \mathrm{FeSO}_{4} / 100 \mathrm{~g}$ WCP; $85.40 \%$ inhibición ACE, C-T: 994.67 mM AAEAA/100g WCP; 310.43 mM FeSO/100g WCP; $61.27 \%$ inhibición ACE y C-Eap1-T: 93.23 mM AAEAA/100g WCP; 23.3 mM FeSO $/ 100 \mathrm{~g} \mathrm{WCP} ; 38.35 \%$ inhibición ACE).

Palabras clave: péptidos antioxidantes, péptidos antihipertensivos, concentrado proteico del suero lácteo bovino, aspartil proteasa de Sporisorium reilianum, enzimas comerciales.

\section{INTRODUCTION}

Whey represents a rich and balanced protein source of amino acids, which allow for a wide range of functional properties. Specifically, whey proteins make up to $20 \%$ of cow milk protein content. Besides their nutritional value (due to their high biological value indexes), in many cases, they also exert biological and physiological effects on the organism (Baró et al., 2001). The presence of leucine, isoleucine, tyrosine, methionine, proline, and valine in the structure of a-Lactalbumin ( $\alpha$-La), $\beta$-Lactoglobulin ( $\beta$-Lg), immunoglobulins (lg), albumin (BSA), lactoferrin (LF), and lactoperoxidase (LP), has given rise to possible applications for the hydrolysis of these proteins to obtain peptides with different biological properties (Muro-Urista et al., 2011; Tovar-Jiménez et al., 2017). Biological properties are partially attributed to peptides encoded in proteins, which are released after proteolytic digestion (Clare and Swaisgood, 2000; Gobbetti et al., 2002). Whey peptides have multifunctional properties such 
as antioxidant, antihypertensive, opioid, and immunomodulatory, among others, and these bioactive peptides are used in products such as infant foods, energy drinks, and hypoallergenic foods to offer added value and improve consumer health (Mensink, 2006; Pfeuffer and Schrezenmeir, 2006).

The release of bioactive peptides from whey proteins has been studied over the past decade, but many of the studies have used only digestive enzymes chymotrypsin (C) and trypsin (T) (Lagrange and Clark, 2018; Maoa et al., 2018; Kamal et al., 2018; Atacan et al., 2016; Rocha et al., 2011; Bayram et al., 2008). Studies on the hydrolysis of these proteins have not yet been carried out using the enzyme Eap 1, produced by the phytopathogen S. reilianum, which has $41 \mathrm{kDa}$ molecular weight and it is an aspartyl protease stable at a wide range of temperatures $\left(4\right.$ to $45^{\circ} \mathrm{C}$ ) and $\mathrm{pH}$ ( 3 to 5 ) values, but $45^{\circ} \mathrm{C}$ and pH 3 are optimal points (Mandujano-González et al., 2013) and shows high proteolytic capacity, because it allows us to obtain hydrolysates with antimicrobial activity higher that that generated by $\mathrm{C}$ and $\mathrm{T}$, and it was also shown that Eap 1 hydrolysates were the only ones that inhibited growth of the yeast C. albicans (Tovar-Jiménez et al., 2017). This suggests it could be used like an important biotechnological alternative in the food industry, in the improvement of bio-functional properties or modulating the techno-functional properties of foods due to its high stability at temperature and $\mathrm{pH}$. Since in recent years much of the scientific interest has focused on finding functional foods or ingredients that contribute to the treatment and prevention of degenerative diseases, the rise of bioactive peptides, as a health issue, still remains open, since peptides obtained and their activity depend on the source of the protein and enzymes used.

Likewise, the enzymatic hydrolysis has not been carried out with the combination of Eap1 with enzymes $C$ and T. Thus, the purpose of the present study was to determine whether the action of Eap1-released peptides presents better biological activity than those released by commercial enzymes $C$ and $T$; in addition, enzymatic cocktails were prepared to determine whether the enzymatic activities of these three enzymes are summative and whether they result in higher levels of antioxidant and antihypertensive activity in the obtained peptides.

\section{MATERIALS AND METHODS}

Ten liters of bovine cheese whey from a cheese industry (México country) were used to obtain whey protein concentrate. Samples of $500 \mathrm{~mL}(511.5 \mathrm{~g})$ of whey were stored at $5{ }^{\circ} \mathrm{C}$ before use. Bovine whey proteins were precipitated with $\left(\mathrm{NH}_{4}\right)_{2} \mathrm{SO}_{4^{\prime}}$ then filtered using nitrocellulose filter paper (Millipore, pore size: $0.45 \mu \mathrm{m}$, and dialyzed using a membrane (Thermo Scientific, pore size: $\mathrm{KDa}$ ). Dialysis was performed until samples reached conductivity $<1 \mu \mathrm{S} \mathrm{cm}^{-1}$ (Tovar-Jiménez et al., 2012).

\section{Microorganism}

The S. reilianum strain was donated by Dr. Santos Gerardo Leyva, of the Universidad Autónoma Chapingo (Mé- xico). It was grown by periodic cultures in YPD-Agar medium (yeast extract $1 \%$, bacto ${ }^{\mathrm{TM}}$ peptone $2 \%$, glucose $2 \%$, and agar $1.5 \%)$, incubated at $28^{\circ} \mathrm{C}$ for 3 days.

\section{Enzymatic hydrolysis}

Purification of the Eap1enzyme, was performed as indicated by Mandujano-González et al. (2013), using anion exchange chromatography with a Bio-Scale Mini UNO sphere Q Cartridge column, coupled to an FPLC system (Bio-Rad). A lineal $\mathrm{NaCl}$ gradient was applied (J. T. Baker $\left.{ }^{\oplus}\right), 1 \mathrm{M}$ in Tris (Sigma $\left.{ }^{\oplus}\right), 20 \mathrm{mM}$ at $\mathrm{pH}$ 8, and the eluted fraction was taken at a $\mathrm{NaCl}$ concentration (J. T. Baker ${ }^{\oplus}$ ) between 0.45 and 0.55 $\mathrm{mol} / \mathrm{L}$, and commercial enzymes of animal origin, trypsin (T) from bovine pancreas (Sigma ${ }^{\oplus}$ ) and chymotrypsin (C) from bovine pancreas (Sigma ${ }^{\oplus}$ ) were used to perform hydrolysis at the enzymatic activity levels of 1.37, 3.13, and $3.7 \mathrm{mUA} /$ $\mathrm{mL}$; hydrolysis was also carried out using four enzyme combinations (Eap1-C, Eap1-T, CT, and C-Eap1-T) at an enzymatic activity level of $1.37 \mathrm{mUA} / \mathrm{mL}$.

Hydrolysis kinetics was carried out from 0 to 120 min at $37^{\circ} \mathrm{C}$ and optimum pH for each individual enzymes and $\mathrm{pH} 6$. The substrate was adjusted to a concentration of $179.4 \mu \mathrm{g}$ WCP protein. The non-hydrolyzed proteins were precipitated with $500 \mu \mathrm{L}$ of $10 \%$ trichloroacetic acid. The reaction mixture was centrifuged at $g$ for $5 \mathrm{~min}$. Finally, the supernatant was used to quantify the peptides released after hydrolysis following the micro-Lowry method as reported by Figueroa-Hernández et al. (2012). Calculation of the peptides released was done on the basis of curve pattern of tyrosine at a concentration of $0-23 \mu \mathrm{g} / \mathrm{mL}$. All determinations were performed in sextuplicate with the following controls: $\mathrm{WCP}+\mathrm{TCA}+$ Enzyme, WCP+Sterile distilled water+Enzyme, and Sterile distilled water+TCA+Enzyme. Finally, the biological activity of the hydrolysis product was determined.

\section{Determination of biological activity of released peptides}

The antioxidant and antihypertensive activities of the peptides released after the enzymatic hydrolysis were analyzed.

\section{Determination of antioxidant activity}

A solution of $7 \mu \mathrm{M}$ ABTS (AMRESCO ultra-pure grade) was mixed with $4.9 \mu \mathrm{M}$ ammonium persulfate (Sigma Aldrich brand) at a 1:1 ratio. The radical ABTS ${ }^{+}$was formed after 16 h. ABTS solution was diluted until reaching absorbance between 0.7 and $754 \mathrm{~nm}$, which was achieved by mixing approximately $40 \mu \mathrm{L}$ of the $\mathrm{ABTS}^{+}$solution with $960 \mu \mathrm{L}$ of absolute ethanol $(\mathrm{v} / \mathrm{v})$. Twenty $\mu \mathrm{L}$ of the sample (released peptides) were added to $980 \mu \mathrm{L}$ of the dilution, and the change in absorbance was measured $7 \mathrm{~min}$ after the reaction. The percentage inhibition of $\mathrm{ABTS}^{+}$radical was calculated using the pattern curve prepared with ascorbic acid [2mM] (MP Biomedicals), in concentrations from 0 to $0.8 \mathrm{mM}$. Data are reported as $\mathrm{mM}$ of antioxidant activity equivalent to ascorbic acid per $100 \mathrm{~g}$ WCP (mM AAEAA/100 g WCP) (Tovar-Jiménez et al., 2012; Mendoza-Jiménez et al., 2018). 


\section{Ferric Reducing Antioxidant Power (FRAP) Assay}

The FRAP assay was performed according to the method described by Luo et al. (2012). In the assay kit with FRAP method, stock solutions include detective buffer, 2,4,6-tripyridyl-s-triazine (TPTZ) solution, and TPTZ solution. The working solution was prepared before use by mixing TPTZ dilution, detective buffer, and TPTZ solution at a ratio of 10:1:1 (v/v/v), respectively, then the working solution was incubated at $37^{\circ} \mathrm{C}$. Fourteen $\mu \mathrm{L}$ of hydrolyzed sample $(0.1 \mathrm{mg}$ peptides $/ \mathrm{mL}$ in PBS) were added to the TPTZ solution (504 $\mu \mathrm{L}$ ) in a eppendorf tube. After incubation for $30 \mathrm{~min}$ at $25^{\circ} \mathrm{C}$, the absorbance of the reaction mixture was measured at 593 $\mathrm{nm}$ with a spectrophotometer. The ferric reducing activity was calculated using the FeSO solution (200 mM-1200 mM) calibration curve and was converted to the $\mathrm{Fe}^{2+}$ antioxidant capacity value, which was expressed as $\mathrm{FeSO}_{4} \mathrm{mM} / 100 \mathrm{~g} \mathrm{WCP}$.

\section{Determination of antihypertensive activity}

The present study used a method described by $\mathrm{Na}$ kamura et al. (1995). Eighty $\mu \mathrm{L}$ of water or $80 \mu \mathrm{L}$ of the sample adjusted to a pH of 8.3, were added to $200 \mu \mathrm{L}$ of the substrate solution, consisting of Hipuryl-Histidyl-Leucine at a concentration of $5 \mathrm{mM}$, dissolved in $0.1 \mathrm{M}$ sodium borate buffer and $0.3 \mathrm{M} \mathrm{NaCl}$, at $\mathrm{pH}$ 8.3. Mixtures were pre-incubated at $37^{\circ} \mathrm{C}$. Twenty $\mu \mathrm{L}$ of ACE (0.1 U/mL, Sigma-Aldrich) were added to initiate the reaction, and the mixture was incubated at 37 ${ }^{\circ} \mathrm{C}$ for $30 \mathrm{~min}$, and then decreasing $\mathrm{pH}$ with $250 \mu \mathrm{L}$ of $1 \mathrm{M}$ $\mathrm{HCl}$ to inactivate the enzyme. The hippuric acid formed in

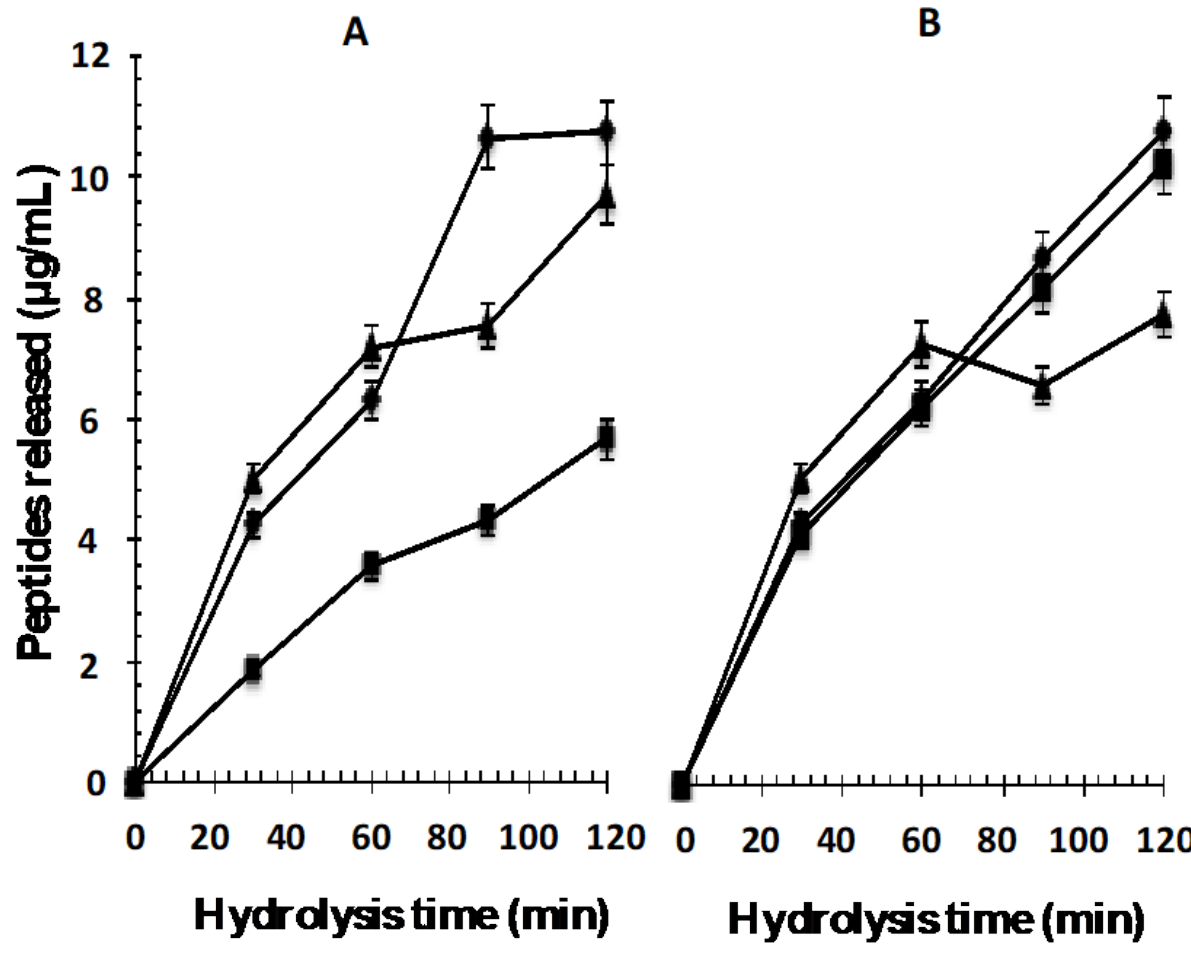

the reaction was extracted by vigorous stirring for $10 \mathrm{~s}$ after adding $1 \mathrm{~mL}$ of ethyl acetate. It was then centrifuged at 4000 $\mathrm{g}$ for $10 \mathrm{~min}$ at $25^{\circ} \mathrm{C}$, and $500 \mu \mathrm{L}$ of the organic phase were withdrawn. Ethyl acetate was removed by heating at $95{ }^{\circ} \mathrm{C}$ for $10 \mathrm{~min}$. The hippuric acid residue was re-dissolved in $1 \mathrm{~mL}$ distilled water, and after shaking, the absorbance at $228 \mathrm{~nm}$ was measured by the spectrophotometer. A reaction target was prepared by adding $\mathrm{HCl}$ prior to the addition of ACE and Captopril was used as the positive control in this study. The activity of each sample was determined in triplicate, and the results were expressed as percentages of ACE inhibition.

\section{Statistical analysis}

For data analysis, the multifactorial analysis of variance methodology was used to determine the individual and joint effects of the factors (enzymatic activity, hydrolysis time and enzyme) on the responses variables (antioxidant and antihypertensive peptides released). Later, the LSD contrast test (minimum significant difference) was performed at a 95\% confidence level. The Statistica 7.0 for Windows statistical program was used. Graphs are expressed in means \pm LSD interval.

\section{RESULTS AND DISCUSSION}

Kinetics of WCP hydrolysis with Eap1, C and T enzymes

Peptides released during hydrolysis of whey proteins depends on the proteolytic activity and time (Figure 1); that is, larger quantities of these compounds are released with

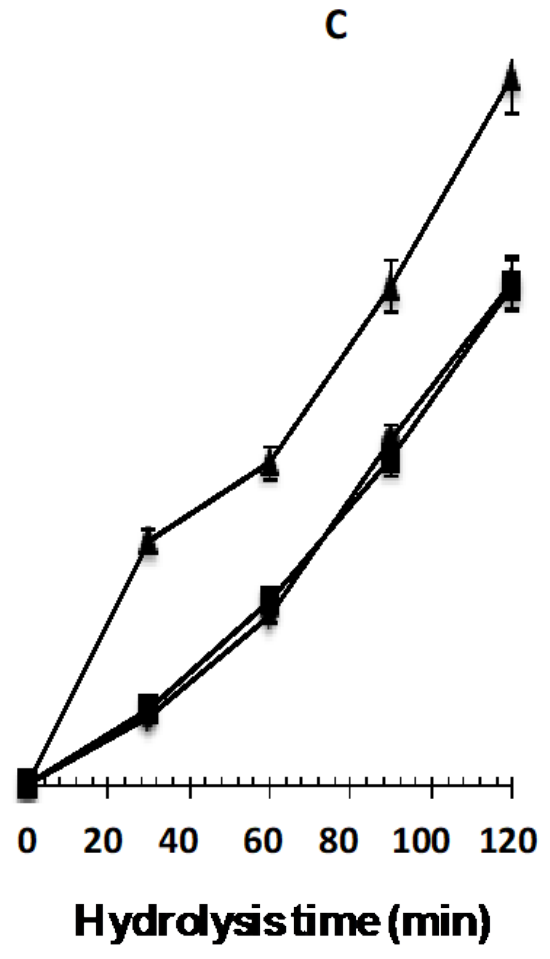

Figure 1: Peptides released from the whey protein concentrate by enzymatic hydrolysis with enzymes A: Eap1, B: chymotrypsin and C: trypsin at different units of enzyme activity $(\boldsymbol{\Lambda} 1.37 \mathrm{mAU} / \mathrm{mL}, \mathbf{\square} .13 \mathrm{mAU} / \mathrm{mL}, 3.71 \mathrm{mAU} / \mathrm{mL})$ and hydrolysis time.

Figura 1: Péptidos liberados del concentrado proteico del suero lácteo por hidrólisis enzimática empleando las enzimas A: Eap1, B: Quimotripsina y C: Tripsina a diferentes unidades de actividad enzimática $(\Lambda 1.37 \mathrm{mUA} / \mathrm{mL}, \mathbf{\square} 3.13 \mathrm{mUA} / \mathrm{mL}, \quad 3.71 \mathrm{mUA} / \mathrm{mL}$ ) y tiempo de hidrólisis. 
Eap1 and $\mathrm{C}$ to $3.71 \mathrm{mUA} / \mathrm{mL}$ without statistically significant differences ( $p>0.05 ; R_{\text {adjusted }}^{2}$ : 0.9056) with the $T$ enzyme to $1.37 \mathrm{mUA} / \mathrm{mL}$ to $120 \mathrm{~min}$ hydrolysis time. The statistical anal$y$ sis showed that there are significant differences $(p<0.05$; $\mathrm{R}_{\text {adjusted }}^{2}$ : 0.9902) between the units of enzymatic activity and the hydrolysis times evaluated. More extensive hydrolysis of WPC with these enzymes may be attributed to their broader specificities to cleave various peptide bonds. In this sense, the aspartyl protease Eap1 prefers to hydrolyze the adjacent carbon, where amino acids phenylalanine, proline, tyrosine, and leucine, while $C$ enzyme hydrolyze the adjacent carbon of amino acids tyrosine, phenylalanine, and tryptophan, and T enzyme hydrolyze preferentially in the adjacent carbon of amino acids arginine and lysine. Likewise, the reaction time only determines the final degree of hydrolysis but the enzyme/substrate ratio directly influences the degree of hydrolysis and composition of the released peptides (Lagrange and Clark, 2018; Maoa et al., 2018; Kamal et al., 2018; Muro-Urista et al., 2011; Zakharova et al., 2009; Peng et al., 2009; Erdmann et al., 2008).

\section{Determination of biological activity of released peptides}

The antioxidant and antihypertensive activities of the peptides obtained from the hydrolysis were measured to determine which enzyme or combination resulted in the most substantial peptide-releasing activity. Our observations show a positive association between the release of bioactive peptides and enzyme activity units (Figure 2, 3 and 4).

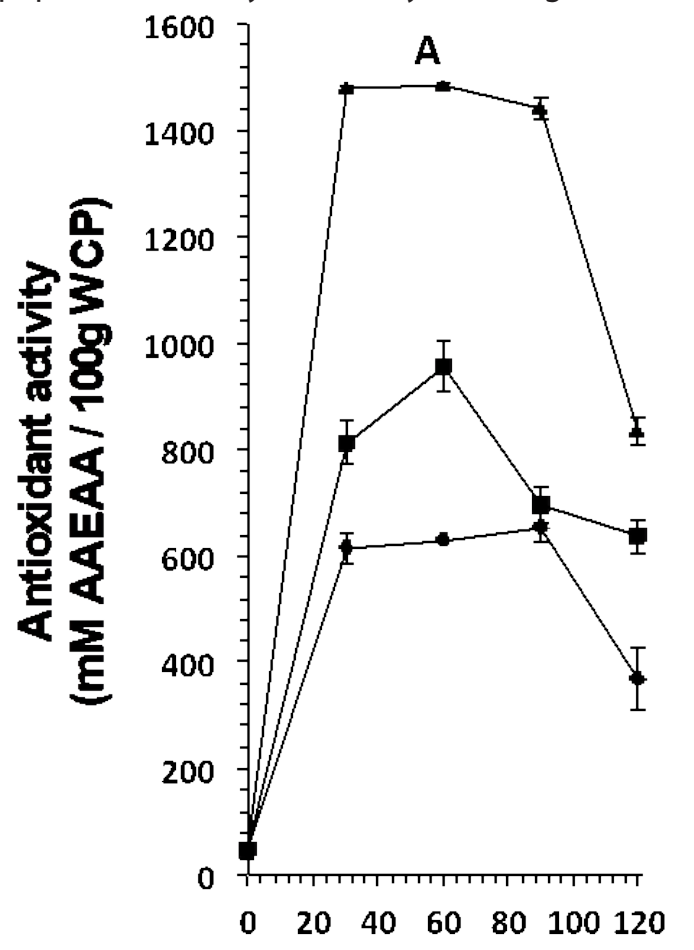

Hydrolysis time (min)
Peptides with antioxidant activity released by the action of Eap1, and enzymes C and T

Figure 2 shows the antioxidant activity of peptides released at different times (0, 30, 60, 90, and $120 \mathrm{~min})$. Eap1-released peptides present better antioxidant activity (1467.30 $\pm 23.86 \mathrm{mM}$ AAEAA/100 $\mathrm{g} \mathrm{WCP}$ ) at an enzymatic activity of $1.37 \mathrm{mUA} / \mathrm{mL}$ in comparison with enzymes $\mathrm{C}(1164.60 \pm 31.25$ $\mathrm{mM}$ AAEAA/100 $\mathrm{g} \mathrm{WCP}$ ) and $\mathrm{T}(354.87 \pm 7.16 \mathrm{mM} \mathrm{AAEAA} / 100$ $\mathrm{g}$ WCP) at the different activity levels studied. Likewise, Figure 3 shows the ferric reducing capacity of peptides released at different hydrolysis time. At an activity of $1.37 \mathrm{mUA} / \mathrm{mL}$, Eap1-released peptides showed better ferric reducing capacity (835.20 $\left.\pm 12 \mathrm{FeSO}_{4} \mathrm{mM} / 100 \mathrm{~g} \mathrm{WCP}\right)$ in comparison with enzymes $C$ and $T$ at the different activity levels studied. The statistical analysis showed significant differences $\left(p<0.05 ; R^{2}\right.$ adjusted: 0.9864 and $\mathrm{R}^{2}$ adjusted: 0.9824 , respectively) between hydrolysis times and enzymatic activities among the different enzymes studied for both studies.

The results obtained in the present study may be due to the fact that Eap1 prefers to hydrolyze the adjacent carbon, where amino acids phenylalanine, proline, tyrosine, and leucine are found (Hedstrom, 2002), which results in the generation of peptides with antioxidant activity, since these peptides require having amino acids such as tyrosine, methionine, tryptophan, and histidine at its terminal carbon as indicated Erdmann et al. (2008). In this sense, The WCP used contained $\beta$-Lg and $\alpha$-La that present 3.7 and $4 \%$ of the amino acid tyrosine in their structures, respectively, which
C

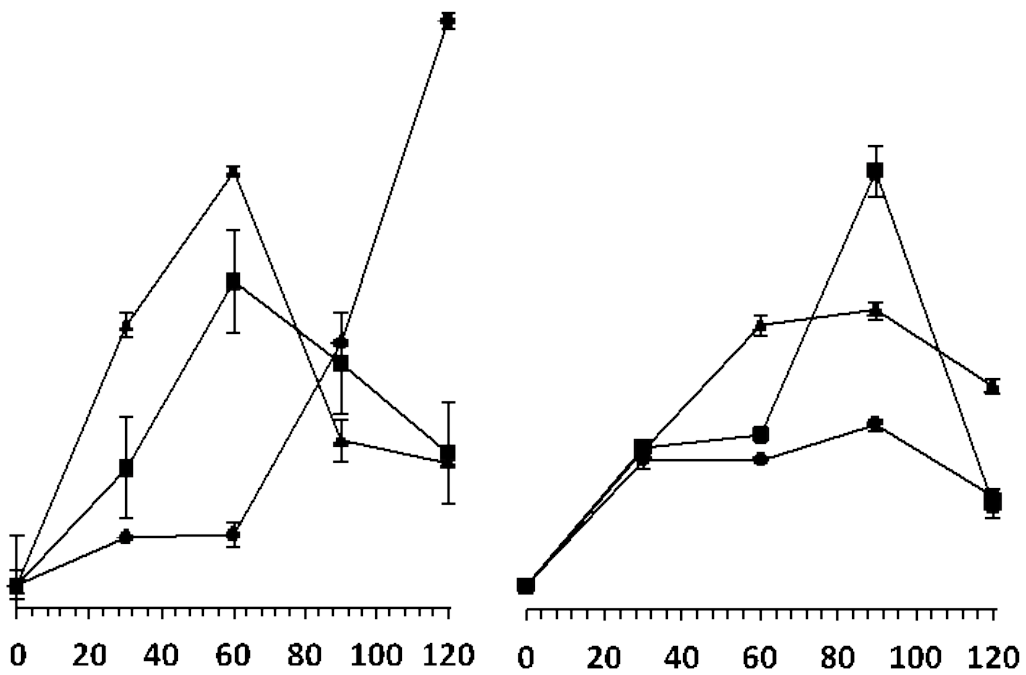

Hydrolysis time (min)

Hydrolysistime (min)

Figure 2: Antioxidant activity of peptides released from the whey protein concentrate by enzymatic hydrolysis with enzymes A: Eap1, B: chymotrypsin and C: trypsin at different units of enzyme activity $(\Delta 1.37 \mathrm{mAU} / \mathrm{mL}, \quad 3.13 \mathrm{mAU} / \mathrm{mL}, \quad 3.71 \mathrm{mAU} / \mathrm{mL})$ and hydrolysis time.

Figura 2: Actividad antioxidante de los péptidos liberados del concentrado proteico del suero lácteo por hidrólisis enzimática empleando las enzimas A: Eap1, B: Quimotripsina y C: Tripsina a diferentes unidades de actividad enzimática $(\boldsymbol{\Delta} 1.37 \mathrm{mUA} / \mathrm{mL}, \mathbf{\square} .13 \mathrm{mUA} / \mathrm{mL}$, $3.71 \mathrm{mUA} / \mathrm{mL}$ ) y tiempo de hidrólisis. 


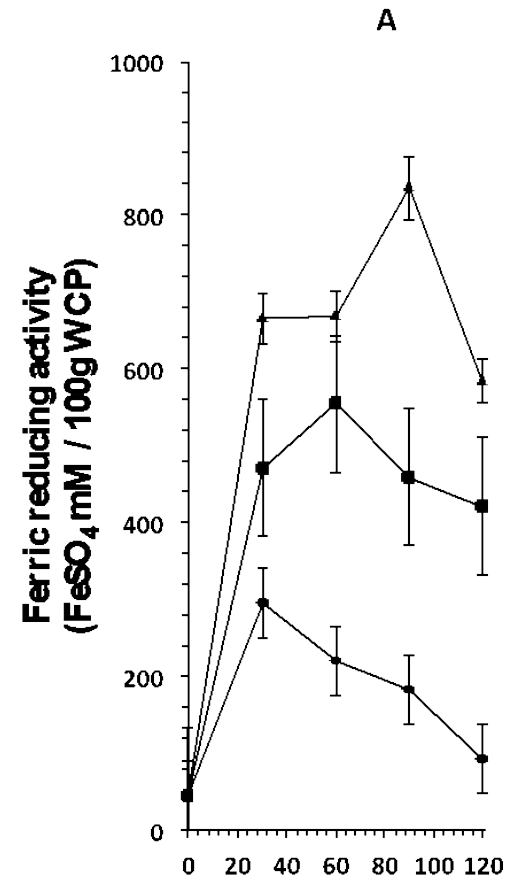

Hydrolysistime (min)
B

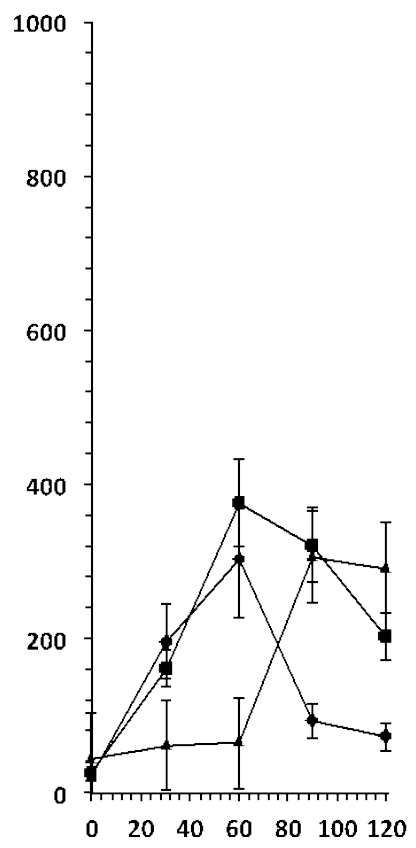

Hydrolysis time (min)
C

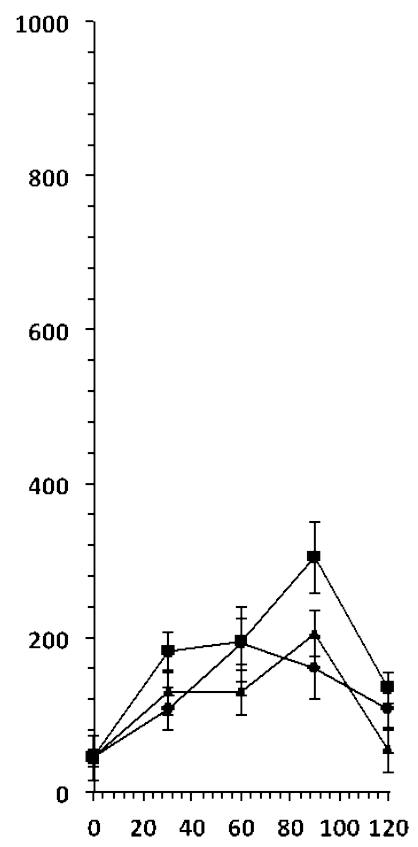

Hydrolysis time (min)

Figure 3: Ferric reducing activity of peptides released from the whey protein concentrate by enzymatic hydrolysis with enzymes A: Eap1, B: chymotrypsin and C: trypsin at different units of enzyme activity $(\boldsymbol{\Delta} 1.37 \mathrm{mAU} / \mathrm{mL}, \mathbf{\square} 3.13 \mathrm{mAU} / \mathrm{mL}$, $3.71 \mathrm{mAU} / \mathrm{mL}$ ) and hydrolysis time.

Figura 3: Potencial reductor férrico de los péptidos liberados del concentrado proteíco del suero lácteo por medio de hidrólisis enzimática con las enzimas A: Eap1, B: quimotripsina y C: tripsina a diferentes unidades de actividad enzimática $(\Delta 1.37 \mathrm{mAU} / \mathrm{mL}, \mathbf{\square} 3.13 \mathrm{mAU} / \mathrm{mL}, \quad 3.71 \mathrm{mAU} / \mathrm{mL}$ ) y tiempo de hidrólisis.

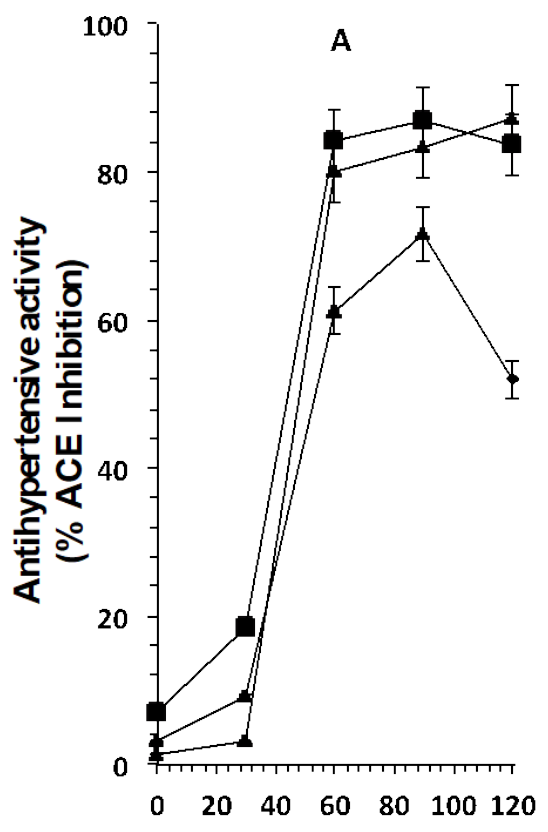

Hydrolysistime (min)

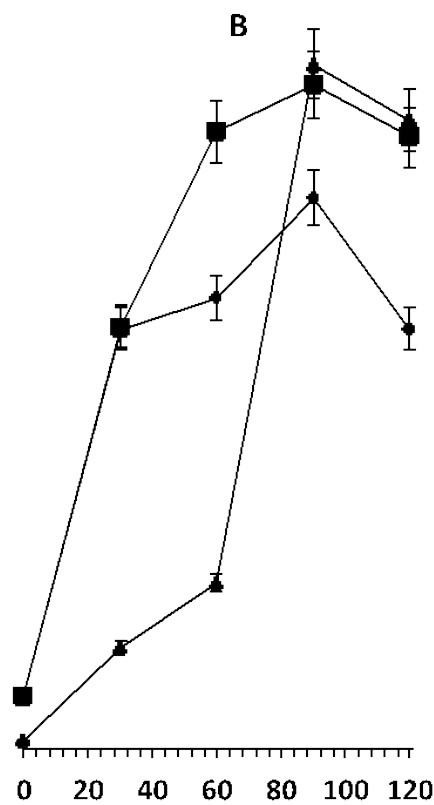

Hydrolysistime (min)

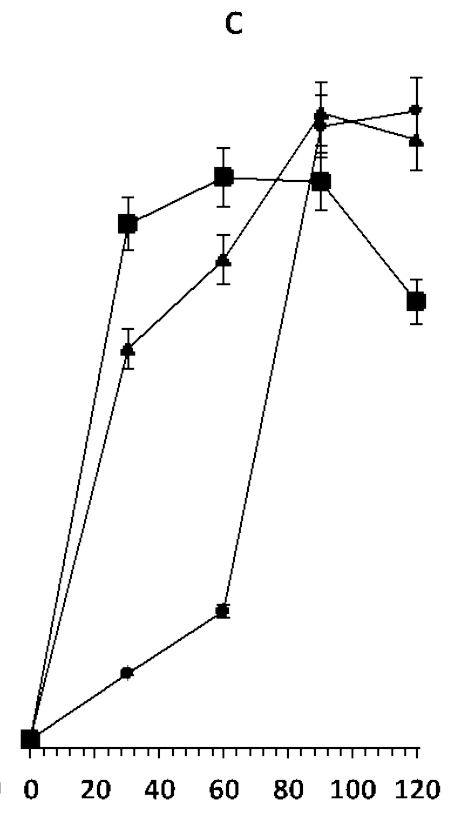

Hydrolysistime (min)

Figure 4: ACE inhibition percentage of peptides released from the whey protein concentrate by enzymatic hydrolysis with enzymes A: Eap1, B: chymotrypsin and C: trypsin at different units of enzyme activity $(\boldsymbol{\Delta} 1.37 \mathrm{mAU} / \mathrm{mL}, \mathbf{\square} 3.13 \mathrm{mAU} / \mathrm{mL}, \bullet$ $3.71 \mathrm{mAU} / \mathrm{mL}$ ) and hydrolysis time.

Figura 4: Actividad antihipertensiva de los péptidos liberados del concentrado proteico del suero lácteo por hidrólisis enzimática empleando las enzimas A: Eap1, B: Quimotripsina y C:Tripsina a diferentes unidades de actividad enzimática ( $\mathbf{\Delta} 1.37$ $\mathrm{mUA} / \mathrm{mL}, \quad 3.13 \mathrm{mUA} / \mathrm{mL}, \diamond 3.71 \mathrm{mUA} / \mathrm{mL}$ ) y tiempo de hidrólisis. 
can be released by the action of Eap1. The fact that peptides presenting lower activity were obtained from hydrolysis with C could be explained because, in this case, the enzyme prefers to hydrolyze the adjacent carbon of amino acids tyrosine, phenylalanine, and tryptophan (Zakharova et al., 2009), and even in the presence of amino acid tryptophan the antioxidant activity is lower than that obtained by Eap 1, because the structures of $\beta$-Lg and $\alpha$-La contain approximately $1 \%$ of this amino acid, and this biological activity also depends on the amino acid sequence and the size of the released peptides (Peña-Ramos and Xiong, 2001; Erdmann et al., 2008; Peng et al., 2009; Muro-Urista et al., 2011). As for the T enzyme, the low activity of the peptides obtained can be attributed to the fact that $\beta-\mathrm{Lg}, \mathrm{BSA}, \mathrm{Lf}$, and Ig are constituted by lysine and arginine (30 and $6 \%, 59$ and $23 \%, 54$ and $37 \%$, and 82 and 84 $\%$, respectively) (Muro-Urista et al., 2011), which may indicate a higher degree of hydrolysis because enzyme T hydrolyzes preferentially in the adjacent carbon of amino acids arginine and lysine (Zakharova et al., 2009) (Figure 1), and as reported by Peña-Ramos and Xiong (2001) and Peng et al. (2009) who indicate that the effect of the antioxidant activity depends on the composition of amino acids, the sequence, and the configuration of the peptides obtained. Moreover, results presented by Peña-Ramos and Xiong (2001) suggest that the degree of hydrolysis exerted by T on $\beta$-Lg is higher compared to the degree exerted by T on $\alpha$-La, generating peptides with lower antioxidant activity. According to Bayram et al. (2008), antioxidant activity is inherent to $\beta-\mathrm{Lg}, \mathrm{BSA}$, and Lf.

\section{Peptides with antihypertensive activity released by the action of Eap1, $C$ and $T$.}

Figure 4 shows antihypertensive activity (ACE inhibition percentage) and hydrolysis time. As can be observed, when WCP hydrolysis was carried out using the three enzymes, with different activity units, peptides with antihypertensive activity were released. Higher levels of biological activity and shorter reaction times were obtained in the present study in comparison with those reported by Hernández-Ledesma et al. (2006), who hydrolyzed $\beta$-Lg from sheep and goat whey using enzymes of animal origin ( $T$ and $C$ ) and reported that, after hydrolysis for $36 \mathrm{~h}$ with $\mathrm{T}$, the peptides obtained from the $\beta$-Lg of ovine origin presented $74.6 \%$ of ACE inhibition, and those obtained from $\beta$ - $\mathrm{Lg}$ of caprine origin presented $73.9 \%$ inhibition after hydrolysis for $24 \mathrm{~h}$. The same authors reported that, when the hydrolysis of $\beta$ - $\mathrm{Lg}$ of ovine and caprine origin is carried out using C, $73.6 \%$ and $64.9 \%$ of ACE inhibition are obtained, respectively, after hydrolysis for $24 \mathrm{~h}$, whereas the released peptides in the present study showed an activity of $83 \%$ of ACE inhibition after hydrolysis for 90 min with Eap1 and T. The statistical analysis showed a significant difference ( $p<0.05, R^{2}{ }_{\text {adjusted }}$ : 0.97$)$ between the time of hydrolysis, enzyme and enzymatic activity evaluated.

These results can be due to the fact that $\beta-L g, B S A$, Lf, and a-La constitute the WCP used, and this activity is inherent to these proteins (Maneva et al., 2003; Prioult et al., 2004). Also, as reported in the literature, peptides that show
ACE inhibitory activity possess hydrophobic residues, such as tryptophan, tyrosine, or phenylalanine, in at least one of the three C-terminal positions where they bind to the ACE active sites, blocking its activity (Aleixandre et al., 2008). It has also been reported that sequences of short chain peptides carrying proline residues, in combination or not with hydrophobic residues, inhibit ACE (Hartmann and Meisel, 2007; Murakami et al., 2004). Additionally, the inhibitory potency can be increased with the presence of positive charges of lysine and arginine in the $\mathrm{C}$-terminal, because they represent $30 \%$ of WCP (Muro-Urista et al., 2011; Hernández-Ledesma et al., 2008; Dziuba et al., 1999).

When analyzing the biological activity results obtained in connection with the three studied activities $(1.37,3.13$, and $3.71 \mathrm{mUA} / \mathrm{mL}$ ) of the evaluated enzymes (Eap1, C, and T), it was decided to use the enzymatic activity of $1.37 \mathrm{mUA} / \mathrm{mL}$, since it presented an acceptable level of biological activity and the process requires a lower amount of enzyme, which could result in lower costs for bioactive peptide production. In this regard, studying an enzymatic cocktail would make it possible to determine whether the enzymatic activities of these three enzymes are summative and their combination results in higher biological activity in comparison with peptides obtained using individual enzymes.

\section{Hydrolysis Kinetics of WCP with the enzymatic combina- tion.}

Four enzyme combinations, aspartyl proteasechymotrypsin (Eap1-C), aspartyl protease-trypsin (Eap1-T), trypsin-chymotrypsin (TC), and aspartyl protease-chymotrypsin-trypsin (Eap1-CT), were evaluated to determine their ability to release bioactive peptides at different times (30, 60,90 , and $120 \mathrm{~min}$ ). Figure 5 show that peptides released during hydrolysis of whey proteins, depends on hydrolysis time and enzyme or enzyme combinations; likewise, that the larger quantities of these peptides are released with enzyme combinations, which suggests a higher degree of hydrolysis, however, biological activity peptides also depends on the composition of amino acids, the sequence, and the configuration of the peptides obtained (Tovar-Jiménez et al., 2017). The statistical analysis showed significant differences ( $p$ $<0.05 ; R^{2}{ }_{\text {adjusted }}: 0.9593$ ) between hydrolysis times and enzyme used.

\section{Antioxidant activity peptides released by enzymatic combination}

Figure 6 shows antioxidant activity (mM AAEAA/100g WCP) with respect to hydrolysis time. As can be observed, enzyme Eap1 (1467.30 $\pm 23.86 \mathrm{mM}$ AAEAA/100 g WCP) and combinations C-T $(994.67 \pm 14.55 \mathrm{mM}$ AAEAA/100 g WCP) and Eap1-C (1050.23 \pm 13.99 mM AAEAA/100 g WCP) released peptides with better antioxidant activity; with no significant differences observed. However, Eap1 released the antioxidant peptides in a shorter time than the combinations. Figure 7 shows the ferric reducing capacity of peptides released at different hydrolysis time, Eap1-released 


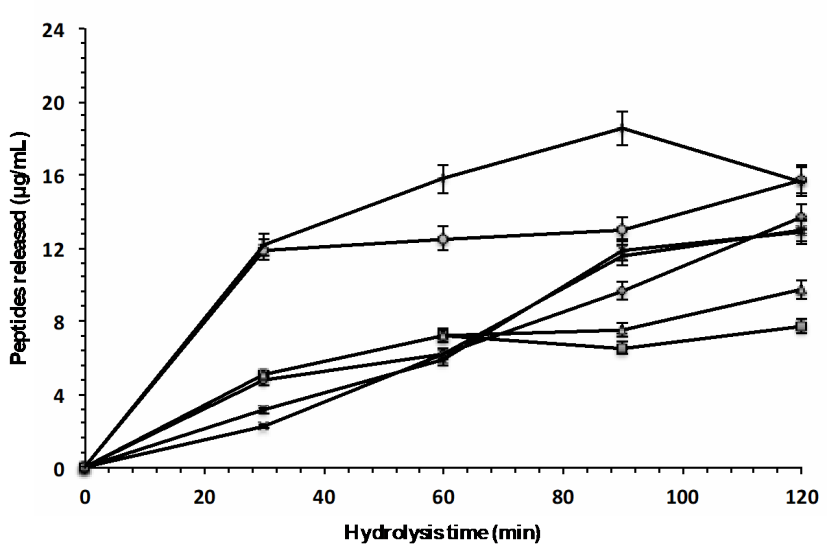

Figure 5: Peptides released from the whey protein concentrate by enzymatic hydrolysis with individual enzymes ( Eap1, $\mathbf{\square}$ chymotrypsin and $\boldsymbol{\Delta}$ trypsin) and with enzymatic cocktail ( $\times$ Chymotrypsin-Eap1, * Trypsin-Eap1, C Chymotrypsin-Trypsin and | Chymotrypsin-Eap1-Trypsin). Figura 5: Péptidos liberados del concentrado proteico del suero lácteo empleando las enzimas individuales ( Eap1, $\square$ Quimotripsina $\Delta$ Tripsina) y las combinaciones enzimáticas ( $\times$ Quimotripsina-Eap1, * Tripsina-Eap1, • Quimotripsina-Tripsina y | Quimotripsina-Eap1-Tripsina).

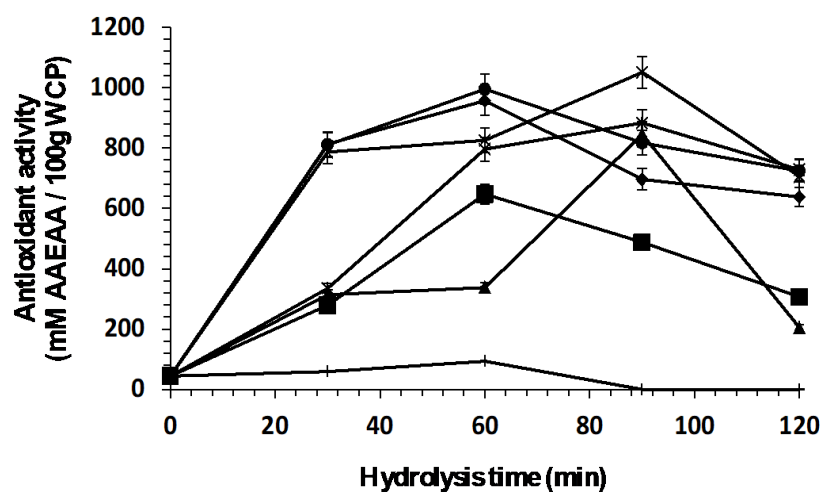

Figure 6: Antioxidant activity of peptides released from the whey protein concentrate by enzymatic hydrolysis with individual enzymes ( Eap1, - chymotrypsin and $\boldsymbol{\Delta}$ trypsin) and with enzymatic cocktail ( $\times$ Chymotrypsin-Eap 1, * Trypsin-Eap1, • Chymotrypsin-Trypsin and | Chymotrypsin-Eap1-Trypsin).

Figura 6: Actividad antioxidante de los péptidos liberados del concentrado proteico del suero lácteo empleando las enzimas individuales ( Eap1, - Quimotripsina $\Delta$ Tripsina) y las combinaciones enzimáticas (× Quimotripsina-Eap1,* Tripsina-Eap1, • Quimotripsina-Tripsina y | Quimotripsina-Eap1-Tripsina).

peptides present better ferric reducing capacity $(835.20$ $\pm 12 \mathrm{FeSO}_{4} \mathrm{mM} / 100 \mathrm{~g} \mathrm{WCP}$ ) in comparison with enzymes $\mathrm{C}$ $\left(305.35 \pm 7.1 \mathrm{FeSO}_{4} \mathrm{mM} / 100 \mathrm{~g} \mathrm{WCP}\right)$ and $\mathrm{T}\left(205.82 \pm 3.2 \mathrm{FeSO}_{4}\right.$ $\mathrm{mM} / 100 \mathrm{WCP}$ ) and enzymatic combinations (Chymotrypsin-Eap1 [399.09 $\left.\pm 5.3 \mathrm{FeSO}_{4} \mathrm{mM} / 100 \mathrm{~g} \mathrm{WCP}\right]$, Trypsin-Eap1 $\left[220.63 \pm 2.8 \mathrm{FeSO}_{4} \mathrm{mM} / 100 \mathrm{~g} \mathrm{WCP}\right]$, Chymotrypsin-Trypsin and Chymotrypsin-Eap1-Trypsin $\left[23.3 \pm 1.5 \mathrm{FeSO}_{4} \mathrm{mM} / 100 \mathrm{~g}\right.$ WCP]). The statistical analysis showed significant differences $\left(p<0.05, R^{2}{ }_{\text {adjusted }}: 0.9307 ; R^{2}{ }_{\text {adjusted: }}: 0.9543\right)$ in hydrolysis times depending on the enzymatic mixture.

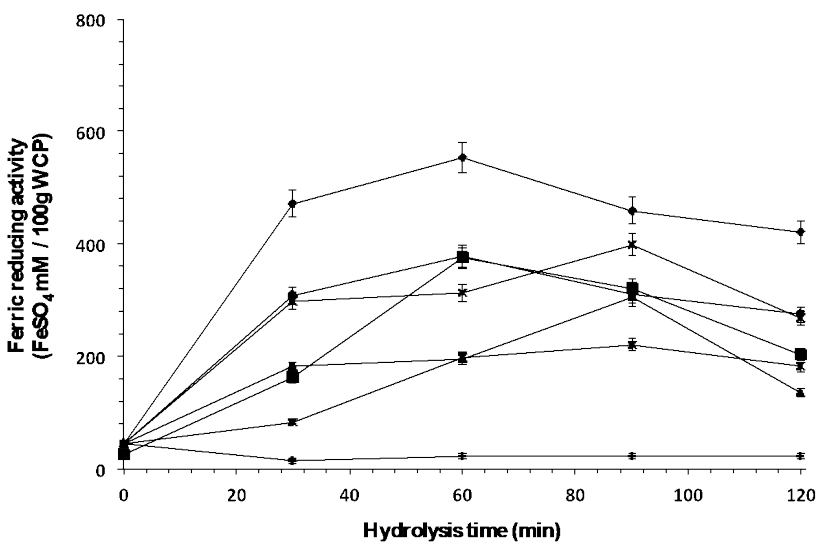

Figure 7: Ferric reducing activity of peptides released from the whey protein concentrate by enzymatic hydrolysis with individual enzymes ( Eap1, chymotrypsin and $\boldsymbol{\Delta}$ trypsin) and with enzymatic cocktail ( $\times$ Chymotrypsin-Eap1, * Trypsin-Eap1, • Chymotrypsin-Trypsin and | Chymotrypsin-Eap1-Trypsin).

Figura 7: Potencial reductor férrico de los péptidos liberados del concentrado proteíco del suero lácteo por medio de hidrólisis enzimática con las enzimas individuales ( Eap 1, quimotripsina y $\boldsymbol{\Delta}$ tripsina) y con el cóctel enzimático (× Quimotripsina-Eap1, * Tripsina-Eap1, • Quimotripsina -Tripsina y | Quimotripsina-Eap1-Tripsina).

\section{Antihypertensive activity peptides released by the action of the enzymatic combination}

Figure 8 shows the percentage inhibition of ACE with respect to hydrolysis time. The enzymatic combination releases peptides with better antihypertensive activity after hydrolysis for 120 min (96 \% ACE inhibition). Similarly, the peptides obtained with enzymes Eap1, C, and the enzymatic combination Eap1-C presented no significant differences; however, Eap1 released these peptides in less time. The statistical analysis revealed that hydrolysis time depends on the enzymatic combination used ( $p<0.05, R^{2}{ }_{\text {adjusted: }}$ : 0.9991 ).

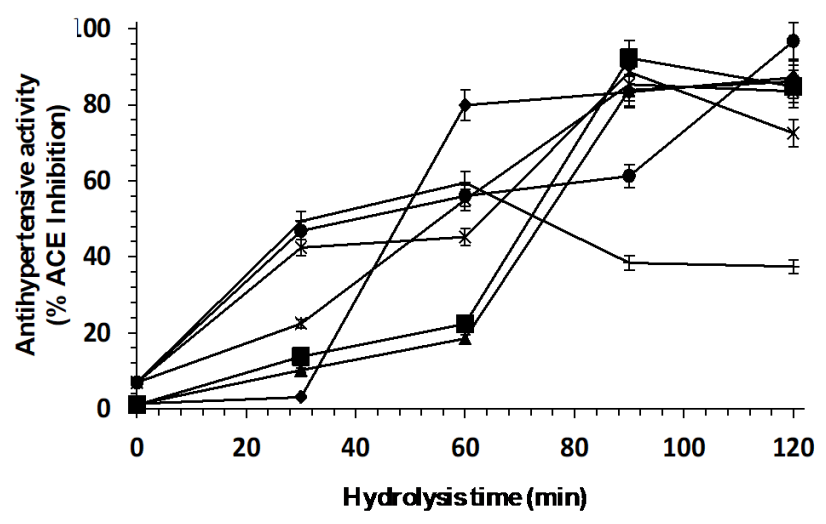

Figure 8: ACE inhibition percentage of peptides released from the whey protein concentrate by enzymatic hydrolysis with individual enzymes ( Eap1, $\mathbf{c h y m o t r y p s i n}$ and $\boldsymbol{\Delta}$ trypsin) and with enzymatic cocktail ( $\times$ Chymotrypsin-Eap1, * Trypsin-Eap1, • Chymotrypsin-Trypsin and | Chymotrypsin-Eap1-Trypsin).

Figura 8: Actividad antihipertensiva de los péptidos liberados del concentrado proteico del suero lácteo empleando las enzimas individuales ( Eap1, Quimotripsina $\Delta$ Tripsina) y las combinaciones enzimáticas ( $\times$ Quimotripsina-Eap1, * Tripsina-Eap1, • Quimotripsina-Tripsina y | Quimotripsina-Eap1-Tripsina). 
The peptides obtained with the different enzymatic combinations, suggest their possible uses in the elaboration of protein hydrolysates for applications requiring higher degrees of protein hydrolysis, than what is possible using individual enzymes (Figure 5). This experimental evidence can be interpreted starting from the fact that proteolytic enzymes act only on peptide bonds containing certain amino acids, for this reason, more substantial hydrolysis is obtained when using enzyme mixtures to maximize hydrolytic action. Our results differ from those reported by Ubalde and Cantera (2002), who used a mixture of Bacillus subtilis protease and obtain whey hydrolysates presenting a low degree of hydrolysis; however, the authors failed to determine the biological activity of such hydrolysates. Nevertheless, the results of our study coincide with those reported by Morris-Quevedo et al. (2001), who evaluated the effect of the use of five enzymatic combinations (bromelain-trypsin, bromelain-pancreatin, papain-bromelain, papain-trypsin, and pancreatin-papain) in obtaining protein hydrolysates from the biomass of the microalgae Chlorella vulgaris previously treated with ethanol; the best results were obtained with the papain-trypsin and papain-pancreatin mixtures. They also state that the use of enzymatic mixtures has a positive effect on the production of hydrolysates presenting a high degree of hydrolysis in comparison with individual enzymes, as shown by the comparison of their hydrolytic actions.

In general, the antioxidant and antihypertensive biological activity results obtained by the hydrolysis of milk serum proteins using individual enzymes (Eap1, C, and T) and enzymatic combinations (Eap1-C, Eap1-T, T-C, and C- Eap1$\mathrm{T})$ show that the best results are obtained when using Eap1 enzyme individually.

\section{CONCLUSIONS}

The aspartyl protease obtained from S. reilianum (Eap1) allows for the obtention of peptides with better antioxidant activity and similar antihypertensive activity in comparison with those obtained using commercial enzymes trypsin and chymotrypsin at $1.37 \mathrm{mUA} / \mathrm{mL}$ under these study conditions.

The peptides obtained using the enzymatic combinations evaluated suggest that their hydrolysates present a higher degree of hydrolysis in comparison with those of individual enzymes.

These findings are interesting because obtaining active peptides by hydrolysis using proteases of fungal origin offers an important biotechnological alternative for the use of an agroindustrial by-product like whey, since Eap1 allows obtention bioactive peptides in less time and with less enzymatic quantity.

\section{REFERENCES}

Aleixandre, A., Miguel, M. and Muguerza, B. (2008). Péptidos hipertensivos derivados de proteínas de leche y huevo. Nutrición Hospitalaria 23, 313-318.

Atacan, K., Cakiroglu, B. and Ozacar, M. (2016). Improvement of the stability and activity of immobilized trypsin on modified $\mathrm{Fe}_{3} \mathrm{O}_{4}$ magnetic nanoparticles for hydrolysis of bovine serum albumin and its application in the bovine milk. Food Chemistry 212, 460-468. https://doi.org/10.1016/j. foodchem.2016.06.011

Baró, L., Jiménez, J., Martínez, A. and Bouza, J.J. (2001). Bioactive milk peptides and proteins. ARS Pharmaceutica 42,135-145.

Bayram, T., Pekmez, M., Arda, N. and Yalcin, A. (2008). Antioxidant activity of whey protein fractions isolated by gel exclusion chromatography and protease treatment. Talanta 75, 705-9. doi: 10.1016/j.talanta.2007.12.007. Epub 2007 Dec 23.

Clare, D.A. and Swaisgood, H.E. (2000). Bioactive Milk Peptides: A prospectus. Journal of Dairy Science 83, 1187-1195. DOI: 10.3168/jds.S0022-0302(00)74983-6

Dziuba, J., Minkiewicz, P., Nalecz, D. and Iwaniak, A. (1999). Database of biologically active peptide sequences. Nahrung-Food 43, 190-195. DOI: 10.1002/(SICI)15213803(19990601)43:3<190::AID-FOOD190>3.0.CO;2-A

Erdmann, K., Cheung, B. and Schroder, H. (2008). The possible roles of foodderived bioactive peptides in reducing the risk of cardiovascular disease. Journal of Nutritional Biochemistry 19, 643-54. DOI: 10.1016/j.jnutbio.2007.11.010

Figueroa-Hernández, C., Cruz-Guerrero, A., Rodríguez-Serrano, G., Gómez-Ruiz, L., García-Garibay, M. and Jiménez-Guzmán J. (2012). Producción de péptidos fijadores de calcio y hierro por Lactococcus lactis subsp. cremoris NCFB 712. Revista Mexicana de Ingeniería Química 11, 259-267.

Gobbetti, M., Morea, M., Baruzzi, F., Corbo, M.R., Matarante, A., Considine, T., Cagno, R., Guinee, T. and Fox, P.F. (2002). Microbiological, compositional, biochemical and textural character1istics of Caciocavallo Pugliese cheese during ripening. International Dairy Journal 12, 511-523. DOI: 10.1016/S0958-6946(02)00042-0

Hartmann, R. and Meisel, H. (2007). Food-derived peptides with biological activity: From research to food applications. Current Opinion in Biotechnology 18, 1-7. https://doi. org/10.1016/j.copbio.2007.01.013

Hedstrom, L. (2002). Serine protease mechanism and specificity. Chemical Reviews 102, 4501-4523. https://doi.org/10.1021/ cr000033x

Hernández-Ledesma, B., Recio, I. and Amigo, L. (2008). $\beta$-Lactoglobulin as source of bioactive peptides. Amino acids. 35(2): 257-265. DOI: 10.1007/s00726-007-0585-1

Hernández-Ledesma, B., Ramos, M., Recio, I. and Amigo, L. (2006). Effect of $\beta$-lactoglobulin hydrolysis with thermolysin under denaturing temperatures on the release of bioactive peptides. Journal of Chromatography A 1116, 31-37. DOI: 10.1016/j.chroma.2006.03.006

Kamal, H., Jafar, S., Mudgil, P., Murali, C., Amin, A., Maqsood, S. (2018). Inhibitory properties of camel whey protein hydrolysates toward liver cancer cells, dipeptidyl peptidaseIV, and inflammation. Journal of Dairy Science 101, 1-10. doi: 10.3168/jds.2018-14586

Lagrange, V. and Clark, D.C. (2018). Nutritive and Therapeutic Aspects of Whey Proteins. En: Whey Proteins, pp. 549-577. Elsevier Inc.

Luo, J., Li, L. and Kong, L. (2012). Preparative separation of phenylpropenoid glycerides from the bulbs of Lilium lancifolium by high-speed counter-current chromatography and evaluation of their antioxidant activities. Food Chemistry, 131:1056-1062. https://doi.org/10.1016/j. foodchem.2011.09.112 
Mandujano-González, V., Arana-Cuenca, A., Anducho-Reyes, M.A., Téllez-Jurado, A., González-Becerra, A.E. and MercadoFlores, Y. (2013). Biochemical study of the extracellular aspartyl protease Eap1 from the phytopathogen fungus Sporisorium reilianum. Protein Expression and Purification 92, 214-222. doi: 10.1016/j.pep.2013.10.003

Maneva, A., Taleva, B. and Maneva, L. (2003). Biofunctional peptides from milk proteins: mineral binding and cytomodulatory effects. Current Pharmaceutical Design 9, 1289-1295. DOI: 10.2174/1381612033454847

Maoa, Y., Krischkea, M., Hengsta, C., Kulozika, U. (2018). Comparison of the influence of $\mathrm{pH}$ on the selectivity of free and immobilized trypsin for $\beta$-lactoglobulin hydrolysis. Food Chemistry 253, 194-202. https://doi.org/10.1016/j. foodchem.2018.01.151

Mendoza-Jiménez, Y.L, Eusebio-Moreno, J.C., Álvarez-García, R., Abreu-Corona, A., Vargas-Hernández, G., Téllez-Jurado, A., Tovar-Jiménez, X. (2018). Actividad antioxidante de los hidrolizados proteicos del frijol común (Phaseolus vulgaris) cv Negro primavera-28 y Flor de Durazno. Revista de Ciencias Biológicas y de la Salud. 2, 25-30.

Mensink, R.P. (2006). Dairy products and the risk to develop type 2 diabetes or cardiovascular disease. International Dairy Journal 16, 1001-1004. https://doi.org/10.1016/j. idairyj.2005.10.013

Morris-Quevedo, H.J., Almares-Asceo, A., Carrillo-Farnés, O., Abdala-Díaz, R.T. (2001). Combinaciones enzimáticas en la obtención de hidrolizados proteicos a partir de Chlorella vulgaris. Revista Cubana Alimentaría Nutrición 15, 85-89.

Murakami, M., Tonouchi, H., Takahashi, R., Kitazawa, H., Kawai, Y. and Negishi, H. (2004). Structural analysis of a new anti-hypertensive peptide ( $\beta$-lactosin $B$ ) isolated from a commercial whey product. Journal of Dairy Science 87, 19671974. https://doi.org/10.3168/jds.S0022-0302(04)70013-2

Muro-Urista, C., Álvarez-Fernández, R., Riera-Rodríguez, F., Arana-Cuenca, A. and Téllez-Jurado, A. (2011). Production and functionality of active peptides from milk. Review. Food Science and Technology International 1, 293-317. doi: 10.1177/1082013211398801.

Nakamura, Y., Yamamoto, N., Sakai, K., Okubo, A., Yamazaki, S. and Takano, T. (1995). Purification and Characterization of Angiotensin I-Converting Enzyme Inhibitors from Sour Milk. Journal of Dairy Science 78, 777-783. DOI: 10.3168/jds.S00220302(95)76689-9
Peng, X., Xiong, Y. and Kong, B. (2009). Antioxidant activity of peptide fractions from whey protein hydrolysates as measured by electron spin resonance. Food Chemistry 113, 196-201. https://doi.org/10.1016/j.foodchem.2008.07.068

Peña-Ramos, E. and Xiong, Y. (2001). Antioxidative activity of whey protein hydrolysates in a liposomal system. Journal of Dairy Science 84, 2577-83. DOI: 10.3168/jds.S00220302(01)74711-X

Pfeuffer, M. and Schrezenmeir, J. (2006). Milk and the metabolic syndrome. Obesity Reviews 8, 109-118. DOI: 10.1111/j.1467789X.2006.00265.x

Prioult, G., Pecquet, S. and Fliss, I. (2004). Stimulation of interleukin-10 production by acidic beta-lactoglobulinderived peptides hydrolyzed with Lactobacillus paracasei NCC2461 peptidases. Clinical and Diagnostic Laboratory Immunology 11, 266-71. DOI: 10.1128/CDLI.11.2.266271.2004.

Rocha, C., Gonçalves, M.P., Teixeira, J.A. (2011). Immobilization of trypsin on spent grains for whey protein hydrolysis. Process Biochemistry 46, 505-511. https://doi.org/10.1016/j. procbio.2010.10.001

Thomä-Worringer, C., Sorensen, J. and López-Fandiño, R. (2006). Health effects and technological features of caseinomacropeptide. International Dairy Journal 16, 132433. https://doi.org/10.1016/j.idairyj.2006.06.012

Tovar-Jiménez, X., Arana-Cuenca, A., Téllez-Jurado, A., Abreu-Corona, A. and Muro-Urista, C. (2012). Traditional Methods for Whey Protein Isolation and Concentration: Effects on Nutritional Properties and Biological Activity. Journal Mexican Chemistry Society 56, 369-377. https://doi. org/10.29356/jmcs.v56i4.246

Tovar-Jiménez, X., Muro-Urista, C., Téllez-Jurado, A., AbreuCorona, A. and Arana-Cuenca, A. (2017). Hydrolysate antimicrobial activity released from bovine whey protein concentrate by the aspartyl protease eap1 of Sporisorium reilianum. Rev. Mex. Ing. Quim. 16, 11-18.

Ubalde, M.C. and Cantera, A.M.B. (2002). Utilización de una mezcla de proteasas para la obtención de hidrolizados de bajo grado de hidrólisis. Información Tecnológica 13, 77-84.

Zakharova, E., Horvath, M.P. and Goldenberg, D.P. (2009). Structure of a serine protease poised to resynthesize a peptide bond. Proceedings of the National Academy of Sciences 106, 11034-11039. DOI: 10.1073/pnas.0902463106 